\title{
Afinal, involução ou expansão demográfica? \\ O esforço de construção do sistema de registros vitais em Minas Gerais entre 1836 e $1850^{*}$
}

After all, involution or demographic expansion?

The effort to build the vital records system in Minas Gerais between 1836 and 1850

Isabella Azevedo Oliveira ${ }^{1}$

Mario Marcos Rodarte ${ }^{2}$

\section{Resumo}

O presente artigo buscou apresentar uma fonte inédita, levantada pelo projeto Antigos regimes demográficos e os registros paroquiais: Minas Gerais, primeira metade do século XIX, realizado pelo Núcleo de Pesquisa em História Econômica e Demográfica - NPHED do Cedeplar/UFMG. A pesquisa teve como propósito estudar o regime demográfico existente em Minas Gerais em meados do Século XIX utilizando uma fonte inédita de dados que são os formulários preenchidos pelos párocos sobre nascimentos, casamentos e óbitos, em atendimento à Lei Provincial de $\mathrm{N}^{\circ} 46$, de 1836, que contribuiu para uma vasta produção de estatísticas vitais e, através da pesquisa, é perceptível as inúmeras possibilidades de estudos da dinâmica demográfica aliando esses registros a outras fontes como, por exemplo, as Listas Nominativas de População. Neste artigo, apresentam-se a fonte, o processo de coleta e o banco de dados construído para divulgação no meio científico e para avaliação das percepções concebidas pela pesquisa.

Palavras-chave: Minas Gerais. Século XIX. Demografia Histórica. Estatísticas de vida. Documentos paroquiais. Política provincial.

\begin{abstract}
This article presents an unpublished historical document raised by the Nucleus of Research in Economic and Demographic History - NPHED of Cedeplar / UFMG. The research had as its purpose to study the demographic regime existing in Minas Gerais in the middle of the XIX Century using an unpublished source of data that are the forms filled by the parish
\end{abstract}

\footnotetext{
* Este artigo trata da exploração de uma fonte inédita de dados e é desdobramento da pesquisa Antigos Regimes Demográficos e os Registros Paroquiais: Minas Gerais no século XIX. Os autores agradecem o Conselho Nacional de Pesquisa Científica (CNPQ) e Fundação de Amparo à Pesquisa de Minas Gerais (FAPEMIG) pelo apoio financeiro a este projeto. O banco de dados e publicações ligadas a ele podem ser acessados no site: http://www.nphed.cedeplar.ufmg.br/revita-minas/.

1 Mestre em Demografia pela Universidade Federal de Minas Gerais. Doutoranda e pesquisadora da Universidade Federal de Minas Gerais. E-mail: isabella.azevedo00@gmail.com

${ }^{2}$ Doutor em Demografia pela Universidade Federal de Minas Gerais, Brasil e Professor Adjunto da Universidade Federal de Minas Gerais. E-mail: mario.rodarte@gmail.com
} 
priests on births, marriages and deaths, in compliance with Provincial Law number 46, of 1836. This was a law that contributed to a vast production of life statistics. Through the research, the innumerable possibilities of demographic dynamics studies are evident, combining these records with other sources, such as the demographic census. In this article we present the historical document, the collection process and the built database, for dissemination in the scientific environment and a brief discussion about its limits and possibilities.

Keywords: Minas Gerais. 19th Century. Historical Demography. Life Statistics. Parish Documents. Provincial Politics.

\section{Introdução}

Nosso objetivo é apresentar uma fonte histórica inédita, resultante da aplicação da Lei Provincial n. ${ }^{\circ}$ 46, de 1836, cujo potencial para o conhecimento da dinâmica demográfica de Minas Gerais na primeira metade do século XIX (1836-1850) apresenta riqueza ímpar. Trata-se de período em que abundam estimativas aproximadas sem lastro empírico. Os dados extraídos dessa fonte podem ajudar a preencher essa lacuna. Procurase, ainda, de forma introdutória, resgatar a história dessa fonte, resumindo as principais características do contexto histórico em que ela foi produzida, analisando seu texto e apresentando suas limitações. Especial atenção será dada aos inúmeros mapas de nascimentos, casamentos e óbitos, da aplicação da Lei quanto a sua cobertura espacial e temporal.

Conforme Bacellar (2008), apontar as limitações de uma fonte não é necessariamente desqualificá-la. Pelo contrário, é uma forma de medir e compreender suas potencialidades, com atenção a questões que podem distorcer as informações geradas através delas. Especialmente para o historiador demógrafo, compreender o que a fonte apresenta para o pesquisador e até onde se pode usá-la sem ajustes é fundamental na análise de estimativas confiáveis e plausíveis do período histórico selecionado para estudo.

A busca de dados torna a tarefa difícil e instigante, ao mesmo tempo. Aliar a análise histórica e a demografia formal é uma tarefa que requer olhar crítico e criatividade, mas, se não há fontes de dados, os atributos destacados anteriormente pouco servem. As fontes, para o demógrafo historiador ou historiador demógrafo, são os verdadeiros limites da pesquisa em demografia histórica. Uma boa pergunta de pesquisa sem dados é somente uma pergunta. 
A documentação que vamos utilizar permite a análise das componentes da dinâmica demográfica do passado, uma vez que se trata de um documento que é a compilação, estatística de dados de nascimentos, casamentos e óbitos. Essa compilação é importante, pois Minas Gerais é considerada uma população em pré-transição demográfica. A transição demográfica é um fenômeno identificado pela mudança de uma população caracterizada por altas taxas de mortalidade e fecundidade para um regime de mortalidade e fecundidade de níveis mais baixos. Quando a população se encontra na pré-transição, a estrutura etária tem o formato clássico piramidal, o crescimento populacional é pequeno, relativamente constante, e a esperança de vida ao nascer é baixa. Contudo, toma-se como resolvida a questão das taxas de mortalidade e fecundidade do passado, especialmente no século XIX, pelo fato de serem classificadas como altas e pela transição demográfica no Brasil começar no século XX. Sendo assim, é importante saber detalhes sobre essas taxas e sobre o comportamento das componentes. Estudos que reconstituam os dados de mortalidade e fecundidade do século XIX possibilitam não só um maior conhecimento sobre essa fase da história demográfica brasileira, como também permitem a comparabilidade com outras localidades que avançaram na construção dessas medidas para o mesmo período.

O objeto deste artigo é a Lei n. ${ }^{\circ} 46$, de 1836 , mote para a produção dos mapas de nascimentos, casamentos e óbitos que trazem informações sobre fecundidade, nupcialidade e mortalidade. É indispensável ressaltar que os mapas de nascimentos, casamentos e óbitos se diferenciam bastante das listas nominativas que trazem a informação por indivíduo. Os mapas trazem os dados no nível agregado, compilados em quadros ou tabelas.

\section{Sobre a evolução da estatística no Brasil Colônia e Império}

Segundo Silva (1870), remete-se ao final do século XVIII e início do XIX o interesse do governo metropolitano em dados demográficos, citando-se levantamentos realizados em 1776, 1808 e 1819, embora esses contenham uma carência expressiva de respaldo estatístico confiável. A mudança do centro político do Império Ultramarino Português de Lisboa para o Rio de Janeiro em 1808 destaca a necessidade de compreensão e melhor administração do território brasileiro e o levantamento populacional é de suma importância, pois reflete a economia e as necessidades do território em questão. Após a Independência do Brasil e fundado o Império Brasileiro, a demanda por estatísticas 
demográficas permaneceu na pauta do governo, tendo a responsabilidade pelos levantamentos populacionais recaído sobre os Conselhos Provinciais desde 18233.

Senra (2006) discorre sobre o retrospecto estatístico no Brasil Império dividindo-o em períodos: Primeiro Reinado (1822-1831), Regências (1831-1840), Consolidação (18401853), Apogeu (1853-1871), Estabilidade (1871-1879) e Declínio e Queda (1879-1889). O período que nos propomos a analisar é compreendido entre o Período Regencial e o Segundo Reinado, compreendendo os anos de 1836 a 1850.

Botelho (1998) levanta questões ligadas à evolução da Estatística Brasileira, ressaltando a sua ineficiência nos períodos coloniais. A relação tensa entre Estado e Igreja no que se refere às questões populacionais além de empecilhos burocráticos da administração do Estado e a falta de responsáveis eficientes para a realização das tarefas são os principais motivos. No Período que tange as Regências e no princípio do Segundo Reinado, Botelho observa uma maior organização da questão estatística que permitiu a elaboração de ricas fontes como as Listas Nominativas para o Período, que permitem a análise de dados em nível de indivíduos com rico detalhamento. É no período que ficou conhecido como Regresso Conservador e durante todo o Segundo Reinado que há o processo de centralização do Estado, permitindo ao governo central tomar para si a responsabilidade sobre a contagem populacional, resultando em censos bem mais expressivos como o censo nacional de 1872. Entretanto, em relação aos mapas de nascimentos, casamentos e óbitos vigora neles a descentralização, sendo uma criação da Província. Na obra de Silva (1870) é destaque uma série de leis provinciais que demandavam levantamentos populacionais e estatísticos no que compreende o período regencial.

\section{Sobre a relação estado-igreja}

Na última década do século XVII, são descobertas riquezas minerais em Minas Gerais, chamando a atenção da Coroa para a região e provocando massivos fluxos de aventureiros para o interior do continente. Esse é um marco da ocupação da capitania que

\footnotetext{
3 Demonstrado também pela criação por meio de um decreto em 25 de Novembro de 1829 da Comissão de Estatística Geográfica, Natural, Política e Civil e da transferência em 1834 da responsabilidade provincial de arrolamentos dos Conselhos de Presidente de Província para as Assembleias Provinciais.
} 
viria nas décadas seguintes a conter expressiva parte da população brasileira. Fonseca (2011) descreve que nesse período desencadeou-se a "marcha da civilização" e da territorialização dos sertões, que foram profundamente transformados pela chegada de uma população numerosa e heterogênea e pela organização político-territorial que o poder metropolitano impôs a sua nova conquista. Segundo Rodarte (2012), a fim de canalizar essas novas riquezas descobertas, a Coroa promoveu o recrudescimento do controle sobre a Colônia. Mecanismos formais e informais foram utilizados nesse processo, promovendo a “interiorização da metrópole na Colônia”, tese originalmente defendida por Dias (1972) e ampliada por Furtado (1999).

A metrópole buscou estreitar laços com a elite branca local, com políticas de manutenção da pureza dos portugueses e descendentes na Colônia. Havia, no entanto, o problema da razão de sexo na região, que favorecia a miscigenação. Segundo Boxer (1969), a escassez de mulheres brancas no ambiente colonial levou à proibição de que se tornassem freiras em Portugal. Esse aspecto mostra como a Igreja atuava em conjunto com o Estado. Mas por que isso ocorria? É importante ressaltar o aspecto do Padroado tanto em Portugal quanto, a posteriori, no Império Brasileiro. Igreja e Estado estariam, portanto, intimamente unidos, atuando em conjunto para moldar a sociedade. $\mathrm{O}$ regime do padroado remete ao privilégio concedido pelo Papa ao rei de Portugal: enquanto Grão-Mestre da Ordem de Cristo, ele poderia escolher bispos e padres, autorizar construções de igrejas, determinar limites de dioceses e receber o dízimo. Privilégio esse concedido em troca das missões evangelizadoras promovidas no cenário colonial, importantíssimas à Igreja, dado o contexto de perda progressiva de fiéis no Velho Continente (FONSECA, 2011, p. 84). Pode-se afirmar que no momento em que a Coroa portuguesa decidiu tomar as rédeas do processo de ocupação da região mineradora, foi através da Igreja que ela procurou se impor e "reduzir toda a gente que anda nas minas e nas povoações" (FONSECA, 2011, p. $82)$.

Segundo a autora, os relatos históricos apontariam que a formação de capelas coincidiria com a formação de núcleos de aglomeração humana estáveis. Dessa forma, o corpo eclesiástico estava sempre próximo dos colonos. É peculiar, no entanto, reforçar um aspecto interessante à ocupação de Minas Gerais: ordens religiosas e conventos foram proibidos de se instalar na capitania, demonstrando um claro interesse metropolitano em não dividir seu poder na colônia, compondo um clero mais secular. Portanto, percebe-se o corpo eclesiástico secularizado pelo Padroado Português na Colônia, como um braço do Estado mais próximo à população, aumentando sua influência em nível local. 
Nessa questão de organização da ocupação, tornas-se necessário colocar as paróquias (ou freguesias) como células-base da organização eclesiástica colonial, sendo estas não apenas centralizadoras das atividades religiosas, mas também de referências administrativas e do fisco. Paróquias comumente se referem não somente ao templo, como também à povoação e aos territórios ocupados pelos habitantes, então chamados fregueses. Esse aspecto linguístico ressalta a ligação Estado-Igreja abordada por Fonseca (2011).

Ainda sobre a forte atuação da metrópole na ocupação da região das Minas, é interessante ressaltar o quão fortemente foi exercido o padroado, seja pela constante indicação de bispos e padres de confiança do rei para as repartições eclesiásticas que cresceram rapidamente com a população das Minas, seja pelo recolhimento do dízimo e sua administração. Nesse aspecto é interessante retomar a ausência de ordens religiosas em Minas Gerais, fazendo com que o próprio Estado arrecadasse o dízimo.

Vale ressaltar também o trabalho de Botelho (1998), que, à luz de fontes como Joaquim Norberto Souza e Silva e diversos escritos de época obtidos no Arquivo Nacional, discorre sobre a ineficiência dos párocos na realização dos recenseamentos populacionais, seja por despreparo ou pelo temor de dividir a paróquia ou aumentar a tributação. Sobre isso, a deficiência sobre os arrolamentos mostra-se crônica:

\begin{abstract}
Também a falta de preparo dos responsáveis pelo trabalho demográfico era um fator limitante da eficácia dos esforços empreendidos. Temos notícias das dificuldades do Conde de Rezende, Vice-Rei no Rio de Janeiro, em conseguir fazer um levantamento da população em 1798 pelo ofício enviado por um capitão-mor em 1799, desculpando-se pelo atraso na remessa de dados devido ao despreparo 5 dos párocos locais e ao pequeno número de respostas obtidas por ele. (BOTELHO, 1998, p. 19).
\end{abstract}

Nesse ponto, percebe-se o atrito entre autoridade civil e autoridade eclesiástica no que tange às questões estatísticas. Não podemos negar a incompletude de muitos registros paroquiais enviados em resposta à Lei $\mathrm{N}^{\circ} 46$, assim como a falta de presteza dos párocos em encaminhá-los no prazo estipulado. Como prova, há reclamações encontradas nos relatórios dos presidentes da província de Minas quanto ao cumprimento, ou não, da referida lei. Como exemplo, no relatório de 25 de março de 1855, o presidente da província Francisco Vasconcellos encarregara Luiz Maria da Silva Pinto, referência no ramo estatístico do período, a fazer um mapa da população. Em seu relatório, ele se queixava de que "insano é o trabalho cometido à perícia desse cidadão, pois que ele teve de compulsar documentos de eras remotas para chegar às conclusões, que poderiam ser mais completas 
se mais abundantes e recentes fossem as fontes a que se refere" (VASCONCELLOS, 1855, p. 36).

Apesar das queixas, foi produzida uma ampla quantidade de mapas. Essa relação íntima entre Estado e Igreja não foi exercida unicamente no período colonial, pois essa articulação institucional foi mantida no Império e permitiu a manutenção do maior controle do Estado sobre populações e territórios. Já criando um laço com os próximos tópicos, a relação Estado-Igreja é essencial aos recenseamentos da população que norteiam esse artigo, uma vez que os párocos foram encarregados de elaborar as estatísticas por determinação da Lei n. ${ }^{\circ} 46$.

No trecho acima, podemos também verificar os primeiros indícios de falha da Lei n. 46, após tentativa do império em laicizar os registros populacionais em 1850 que gerara uma revolta popular e fora motivo de progressivo abandono dos registros de nascimentos e óbitos por parte dos párocos, que perderiam prestígio social, assim como a côngrua destinada pela tarefa, com a medida imperial (SENRA, 2006, p.150). Não tardaria até que o Império tomasse para si a tarefa de registrar a população e suas atividades econômicas, tal qual encontrado no primeiro censo imperial de 1872.

\section{A Lei Provincial n. ${ }^{\circ}$ 46, de 1836}

Em 18 de março de 1836, foi promulgada, pelo presidente de Província, Manoel Dias Toledo, a Lei n. ${ }^{\circ} 46^{4}$. Nela, há dois Capítulos: Estatística Annual e Estatística Decennal. A Lei foi resultado de um período descentralizador, que permitiu certa autonomia das Províncias (DINIZ; RODARTE, 2014).

O Capítulo I, Estatística Annual, determinou aos párocos quais eram as informações obrigatórias para preenchimento e como conservar os livros de registro de nascimentos, casamentos e óbitos. Nele, há indicações de como os párocos deveriam realizar o preenchimento e como lidar com casos diferenciados, por exemplo, de crianças expostas para adoção, impedimentos no casamento, falecimento em prisões, entre outros. Os Fiscais e Juízes de Paz tinham a função de acompanhar a execução da Lei, podendo aplicar penalidades por omissão de registro. Os artigos 15, 16, 17 e 18 são importantes para

\footnotetext{
4 A referida lei encontra-se na íntegra no endereço: http://memoria.bn.br/DocReader/docreader.aspx?bib=253634\&PagFis=208
} 
este artigo, pois neles é formalizada a confecção semestral de mapas que deveriam conter todos os nascimentos, casamentos e óbitos ocorridos na paróquia e registrados nos livros. $\mathrm{O}$ artigo 15 indicava que o modelo a ser usado pelos párocos seria enviado pelo governo. Os mapas deveriam ser enviados ao Presidente de Província, que organizaria um mapa geral semestral dos eventos e, no começo de cada ano, um mapa total, que seria apresentado à Assembleia Legislativa Provincial. Para a execução dessa função, os párocos recebiam cinquenta mil réis por semestre. Os que não cumprissem o envio dos mapas, um mês após o término do semestre, não seriam gratificados. Sobre a população coberta nos livros e, consequentemente, nos mapas, os artigos 8 e 22 do referido Capítulo são importantes, ao destacar que nos livros não seriam excluídos aqueles que não fossem católicos e nem os escravos.

§Art. $8^{\circ}$ Quando os Contrahentes não professarem a Religião do Província, farão, no mais curto prazo possível, a mencionada declaração ao Parocho, ou ao seu Vice-Gerente. Neste caso a obrigação é extensiva à Authoridade, perante quem houverem celebrado o contracto. (Livro da Lei Mineira, Lei 46 de 1836, p. 30)

$\S$ Artigo $22^{\circ}$ Esta Lei não exonera os Parochos de fazerem nos mesmos Livros, mas em uma parte distinta d'elles, os registros dos nascimentos, cazamentos, e óbitos, que tiverem lugar entre escravos. (Livro da Lei Mineira, Lei 46 de 1836, p. 31 e 32)

O Capítulo II, Estatística Decennal, normatizou a execução, a cada dez anos, de um arrolamento geral da população da Província. Os itens essenciais nesse recenseamento são semelhantes aos das listas nominativas, lembrando que esta Lei foi criada após a experiência de confecção das listas de 1831 e 1832. Esse arrolamento deveria conter nome, sexo, ocupação, província, condição e capacidade de ler. O resultado desse levantamento seria divulgado em algum local público, durante um mês, para possibilitar solicitações de alterações.

A Lei $n .^{\circ} 46$ foi importante em diversas esferas. Foi uma lei que formalizou e reforçou a importância dos livros de registro dos párocos e conferiu a esses livros uma importante função, pois eles seriam o insumo dos dados agregados a serem apresentados à Assembleia Legislativa Provincial. Esse fato, somado à definição do recebimento de gratificações aos párocos para a execução das atividades impostas na lei, corrobora a forte relação entre Igreja e Província, já ressaltada anteriormente. Além disso, a formalização de um arrolamento decenal de habitantes foi importante, no sentido de demonstrar uma 
preocupação da Província em sistematizar a contagem populacional, num período anterior ao dos censos oficiais.

O Capítulo I da lei, que formalizou a execução dos mapas, que tinham como fonte os registros eclesiásticos, determinou que o Governo providenciaria os modelos dos referidos mapas. Esse modelo veio através do Regulamento $8^{5}$, de 24 de outubro de 1836, que reforçou as diretrizes da Lei $n .^{\circ} 46$ e apresenta os modelos dos mapas para cada registro (nascimento, casamento e óbitos), os modelos para confecção do arrolamento populacional decenal e o mapa de população.

Art. $3^{\circ}$ Os Parochos terão o maior cuidado de instruir os seus Freguezes nas obrigações, que lhes são impostas pela Lei, lembrando-lhes principalmente as declarações, que eles tem de fazer, relativas aos nascimentos, casamentos, e óbitos; o que poderão cumprir, ou por meio de Editaes repetidas vezes afixados nas portas das Matrizes, e Capella, ou por outros quaisquer meios, que lhes forem sugeridos pelo zelo que os deve constantemente animar a bem do serviço publico, e da fiel, e exacta observância das Leis. (Livro da Lei Mineira, Regulamento 8, de 1836, p. 19)

Abaixo seguem os modelos de mapas que foram preenchidos pelos párocos, com base nos livros de registro de nascimentos, casamentos e óbitos.

Figura 1 - Modelo número 1 - Mappa dos Nascimentos - Regulamento 8 de 1836

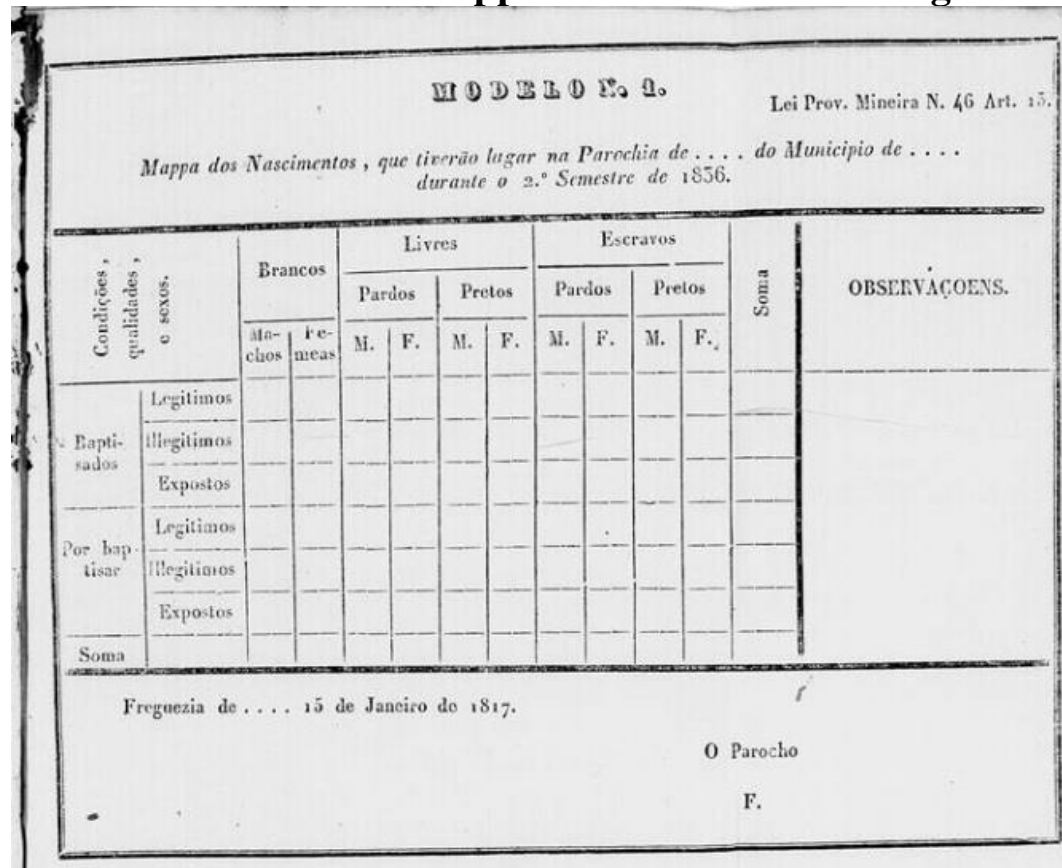

Fonte: Biblioteca Nacional (BN) - Livro da Lei Mineira, Regulamento 8, de 1836, p. $25^{6}$.

$5 \mathrm{O}$ regulamento encontra-se na íntegra no endereço:

http://memoria.bn.br/DocReader/docreader.aspx?bib=253634\&PagFis=298

${ }^{6}$ Livro da Lei Mineira: Regulamento 8 de 1836, p.25. Disponível em:

http://memoria.bn.br/DocReader/docreader.aspx?bib=253634\&PagFis=298. Acesso em: 15 set. 2016. 
Figura 2 - Modelo número 2 - Mappa dos Cazamentos - Regulamento 8, de 1836

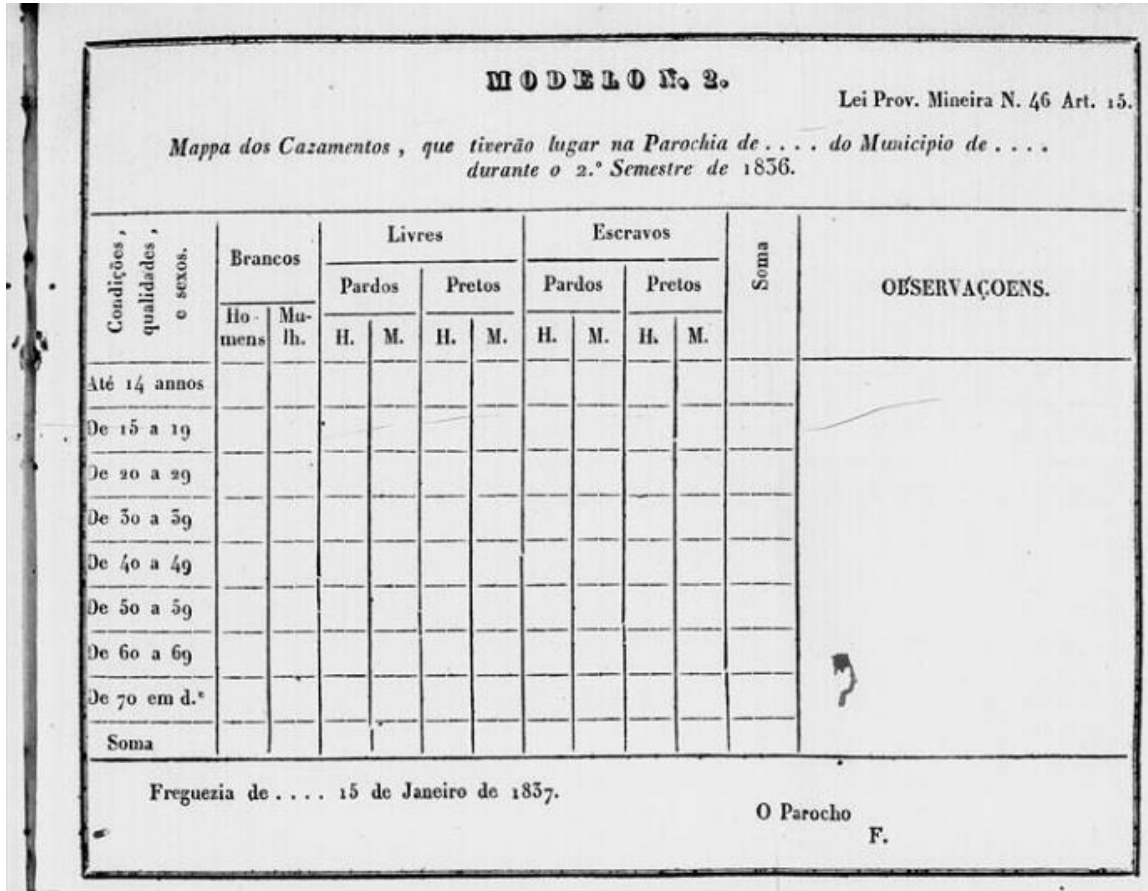

Fonte: BN - Livro da Lei Mineira, Regulamento 8, de 1836, p. $26^{7}$

${ }^{7}$ Livro da Lei Mineira: Regulamento 8 de 1836, p.26. Disponível em:

http://memoria.bn.br/DocReader/docreader.aspx?bib=253634\&PagFis=298. Acesso em: 15 set. 2016. 
Isabella Azevedo Oliveira e Mario Marcos Rodarte

Figura 3 - Modelo número 3 - Mappa dos Óbitos - Regulamento 8, de 1836

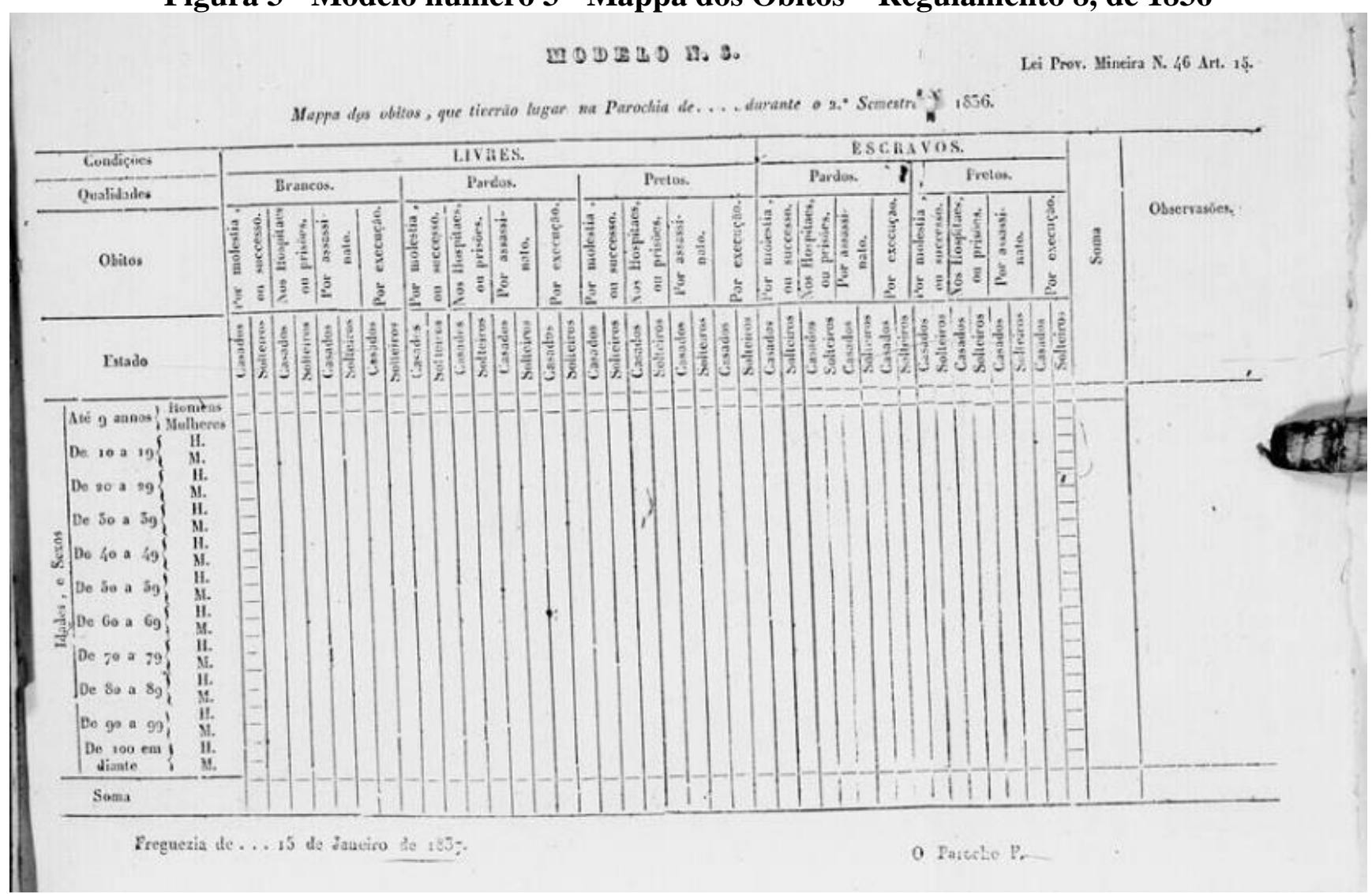

Fonte: BN - Livro da Lei Mineira, Regulamento 8, de 1836, p. $27^{8}$.

${ }^{8}$ Livro da Lei Mineira: Regulamento 8, de 1836, p.27. Disponível em: http://memoria.bn.br/DocReader/docreader.aspx?bib=253634\&PagFis=298. Acesso em: 15 set. 2016. 
Os modelos apresentados no Regulamento número 8 são instigantes. Percebe-se a preocupação em considerar a condição jurídica dos indivíduos, bem como a qualidade (branco, pardo e preto) ${ }^{9}$, sexo e faixas etárias decenais (exceto para o mapa de nascimentos, que buscava compilar a legitimidade dos nascidos). Para a época, mostrase interessante e vanguardista a iniciativa da Província. Claro que, apesar de extremamente inovador e avançado, os mapas em questão estavam sujeitos a diversos problemas como declaração errônea de idade e de qualidade, por exemplo. Silva (1870) destaca que a Lei n. ${ }^{\circ} 46$ e o Regulamento número 8 resultaram em uma ampla produção de mapas de nascimentos, casamentos e óbitos durante 15 anos, de 1836 a 1850, como, de fato, a pesquisa veio a constatar, agora, pelo rico acervo remanescente no APM.

A Lei Provincial n. ${ }^{\circ}$ 46, de 1836, de Minas Gerais, teve repercussão rápida na província e houve respostas interessantes em forma de mapas de nascimentos, casamentos e óbitos ainda na década de 1830. Para o ano de 1838, por exemplo, temos o envio de cerca de 444 mapas de nascimentos, casamentos e óbitos, que abrangem 65 paróquias. O Estado de deterioração de alguns mapas e sua possibilidade de extravio ao longo de quase dois séculos desde que foram elaborados é uma ressalva a maior abrangência da fonte. No entanto, a presença de documentos que indicam natalidade e mortalidade em uma série de paróquias no decorrer de pouco mais de duas décadas nos permite observar a dinâmica populacional do período, tornando essa nova fonte de dados um dado complementar de grande importância para entender a população mineira nos oitocentos.

\section{Levantamento dos mapas}

O levantamento dos mapas foi realizado in loco no Arquivo Público Mineiro (APM) em Belo Horizonte, Minas Gerais. A pesquisa buscou coletar todos os mapas disponíveis para a consulta. Esses registros estão disponíveis em duas coleções: Presidente de Província (PP1-10) e Mapas de População (MP). Ao todo foram coletados

\footnotetext{
9 "Qualidade" foi parte do léxico do setencentos e oitocentos antes da compreensão que temos sobre raça na contemporaneidade, para mais informações ver PAIVA $(2015,2016)$. A qualidade não estava somente vinculada a cor da pele, mas também a sua ocupação, reputação e condição socioeconômica. A divisão por qualidade veio definida no modelo e não há na Lei n. ${ }^{\circ} 46$ ou no Regulamento n. ${ }^{\circ} 8$ uma explicação de como foi concebida essa categorização. Ao que tud indica, a categoria pretos incluía negros, pretos e crioulos.
} 
879 mapas, porém há mapas passando por processo de restauração e tratamento de fungos, logo, essa coleta não contempla todo o acervo do APM. O ano de 1838 tem o maior número de mapas produzidos, conforme Tabela 1, mostrando o impacto na produção e conservação do material referente a esse ano, sendo uma das justificativas da escolha temporal de análise que será apresentada a seguir.

A coleta foi realizada através de planilhas eletrônicas, que replicaram os modelos fornecidos pelo Regulamento número 8, de 1836. O objetivo principal foi coletar os mapas de maneira que replicassem os originais, para, posteriormente, serem disponibilizados em base de dados online pelo NPHED. Com os mapas coletados em planilhas eletrônicas, tornou-se mais prático o manuseio das informações para construção de bases de dados.

TABELA 1 - Balanço da Coleta dos Mapas de Nascimentos, Casamentos e Óbitos Pesquisa: Antigos regimes demográficos e os regimes paroquiais, primeira metade do século XIX

\begin{tabular}{ccccc}
\hline \hline Ano de Referência & Nascimentos & Casamentos & Óbitos & Total \\
\hline 1836 & 20 & 21 & 19 & 60 \\
1837 & 20 & 20 & 17 & 57 \\
1838 & 147 & 146 & 151 & 444 \\
1839 & 0 & 0 & 0 & 0 \\
1840 & 0 & 0 & 0 & 0 \\
1841 & 30 & 28 & 27 & 85 \\
1842 & 13 & 13 & 12 & 38 \\
1843 & 1 & 1 & 1 & 3 \\
1844 & 0 & 0 & 0 & 0 \\
1845 & 26 & 27 & 29 & 82 \\
1846 & 9 & 7 & 7 & 23 \\
1847 & 15 & 15 & 15 & 45 \\
1848 & 0 & 0 & 0 & 0 \\
1849 & 7 & 7 & 7 & 21 \\
1850 & 7 & 7 & 7 & 21 \\
\hline Total & 295 & 291 & 293 & 879 \\
\hline \hline
\end{tabular}

Fonte: Banco de dados da coleta do NPHED da pesquisa Antigos Regimes demográficos e os regimes paroquiais, primeira metade do século XIX. 


\section{Figura 4 - Mapa de óbito feito à mão - Arquivo Público Mineiro}

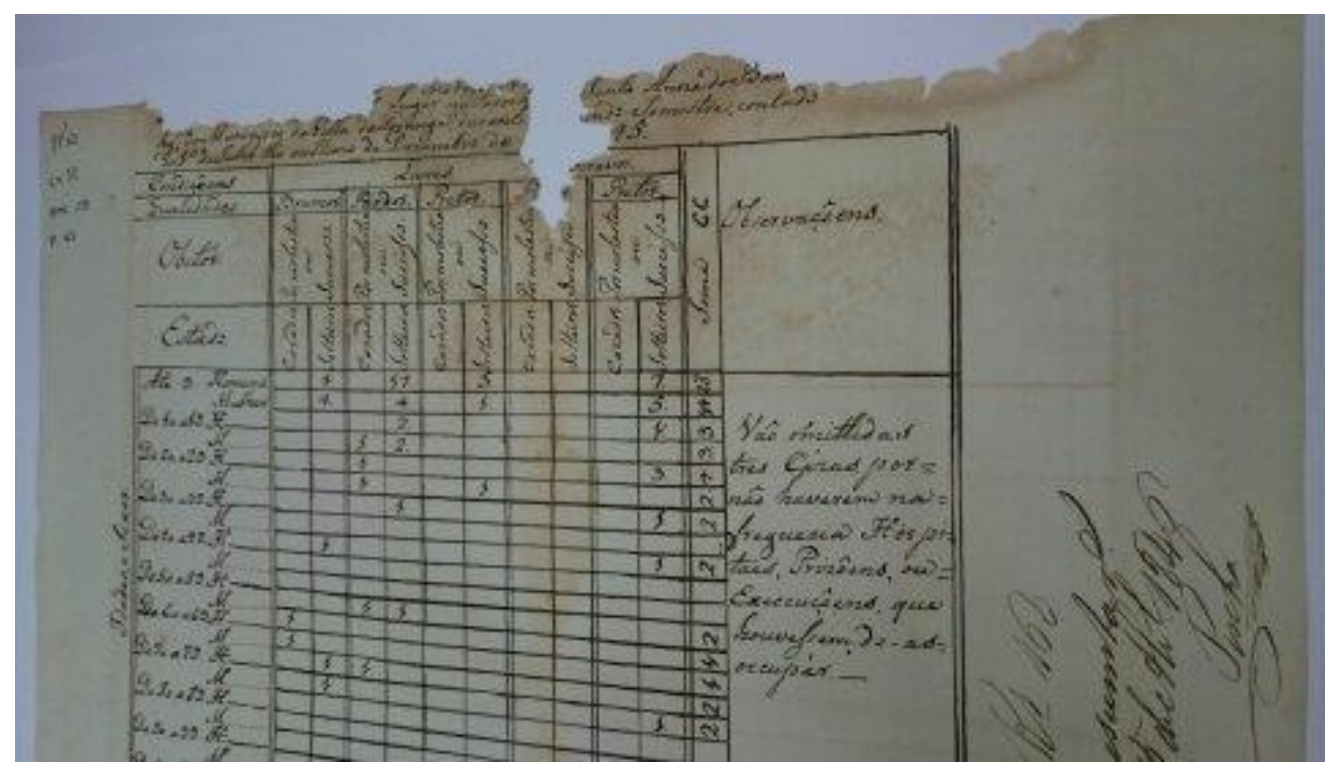

Fonte: Fotografia elaborada pelos autores, $2016^{10}$.

Na coleta, foi possível identificar algumas particularidades dos mapas, que são interessantes para análise e compreensão não só das informações constantes nesses documentos, mas, também, para resgatar o contexto da época. Alguns párocos não seguiram fielmente as diretrizes da Lei $\mathrm{n} .^{\circ} 46$, de 1836 , e fizeram mapas anuais e não semestrais. Outra informação interessante foi a quantidade de mapas feitos à mão no início e posteriormente houve uma mudança para versão impressa feita pela Imprensa Oficial de Ouro Preto. Os mapas feitos à mão respeitavam, em geral, as diretrizes do modelo proposto. A única distinção percebida é a apresentada na Figura 4, em que é perceptível uma aglutinação nas causas/locais de morte. Exceto esse ponto, não foram encontradas outras abreviações, pois os mapas escritos à mão sempre continham as faixas etárias decenais, qualidade, sexo, Província civil e condição jurídica.

O campo de observações trouxe curiosas declarações dos párocos, que instigam mais o estudo dessa fonte e a tornam menos impessoal. O pároco Francisco Jorge, responsável pela Paróquia do Turvo, do Município de Aiuruoca, relata em 1838:

O número de mortos nesta Freguesia vem diminuto: achão-se pessoas de varias coalidades e Províncias. Contão-se alguns, sabendo que parócos, de seculo, e naturais desta Freguesia talvez perceba isto à sabedoria. Nem hum faleceu nos hospitais ou prizões, cujos estabelecimentos ainda aqui não existem: assim como, nem hum assassinato, nem uma execução. (Francisco Jorge, 1838, Mapa de óbitos da Freguesia do Turvo)

\footnotetext{
${ }^{10}$ Fotografia elaborada pelos autores. O documento encontra-se, fisicamente, no Arquivo Público Mineiro de Belo Horizonte/MG, na seção de arquivos Presidente de Província PP1-10.
} 
O mesmo pároco relata, em 1841, que "o número de mortos nesta freguesia há diminuto: talvez se deva a salubridade do ar. Há habitantes de setenta e oitenta anos naturais do país. Nem hum dos mortos faleceram em hospitais ou prizões, o mesmo assassinato e execução”. Francisco Villela, pároco da Freguesia de Nossa Senhora do Bom Sucesso de Serranos relata, em 1846, que houve mortes de febre e pintinhas.

Esses são alguns exemplos da infinidade de abordagens que essa fonte permite, desde uma análise qualitativa dos comentários, a análises quantitativas das componentes demográficas.

\section{Figura 5- Mapa de óbito versão impressa - Arquivo Público Mineiro}

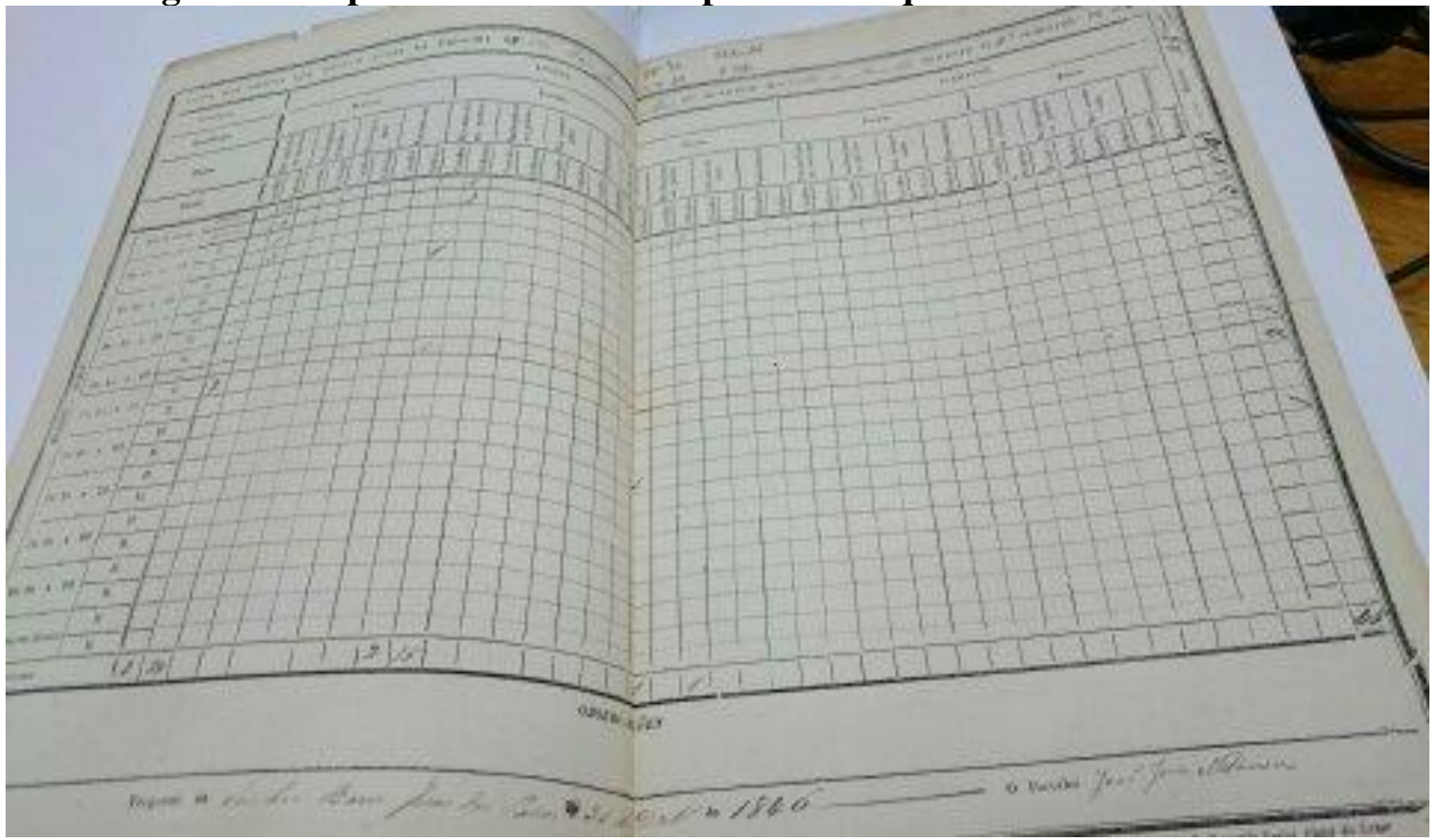

Fonte: Fotografia elaborada pelos autores, 2016. ${ }^{11}$

A expressiva quantidade de mapas para o ano de 1838 mostra que, até o momento, é o período com maior potencial de análise. O banco de dados preliminar construído e apresentando é referente a esse ano. Ressalta-se, do mesmo modo, a falta de consistência em quantidade de mapas por ano, o que levanta a hipótese se 1838 foi um ano com maior produção ou foi um ano com melhor conservação do material proveniente da Lei. Na sequência, vamos abordar o tratamento das informações e a construção do banco de dados.

\footnotetext{
${ }^{11}$ Fotografia elaborada pelos autores, o documento encontra-se, fisicamente, no Arquivo Público Mineiro de Belo Horizonte/MG, na seção Presidente de Província PP1-10.
} 


\section{Tratamento das informações e construção do banco de dados de 1838}

Para construção do banco de dados e avaliação do volume de informação de 1838 foi realizado, a priori, uma análise espacial da informação por meio do georreferenciamento das paróquias com informações disponíveis.

\section{A. Georreferenciamento e cobertura}

Com o georreferenciamento das paróquias buscou-se, primeiramente, fazer a conexão entre paróquias e distritos, o que foi facilitado pelo conhecimento acumulado sobre localização de povoados e nucleações urbanas existentes na década de 1830, por pesquisas anteriores do NPHED. Os distritos constituíam a menor unidade administrativa geográfica na época e as paróquias eram unidades eclesiásticas que abarcavam um ou mais distritos. Para este e outros estudos, estabelecer as relações entre ambos se torna necessário, uma vez que elaborações de indicadores com bases nos registros paroquiais devem ter, como denominadores, os dados de população, obtidos pelos registros censitários, conhecidos como listas nominativas, quer eram distritais. Como indica o Erro! Fonte de referência não encontrada., o fragmento do recenseamento de 1830, preservado no Arquivo Público Mineiro e transformado em banco de dados digital ${ }^{12}$, tem cobertura ampla, de cerca de $60 \%$ dos distritos existentes, e é bem representado em todas as regiões e níveis de desenvolvimento socioeconômico $^{13}$.

\footnotetext{
${ }^{12}$ As Listas Nominativas da década de 30 estão disponíveis no site www.nphed.cedeplar.br

${ }^{13}$ A regionalização apresentada no mapa é creditada a proposta feita por Godoy (1996). O seu trabalho, com base em livros de relatos de viagem e outras fontes, consegue captar espaços com identidades regionais de Minas Gerais, na primeira metade do século XIX. Na sequência, as mesmas regiões foram organizadas por níveis de desenvolvimento socioeconômico por Paiva (1996).
} 
Mapa 1: Sedes dos distritos de paz em relação ao recenseamento, por região e níveis de desenvolvimento regionais - Minas Gerais - Década de 1830.

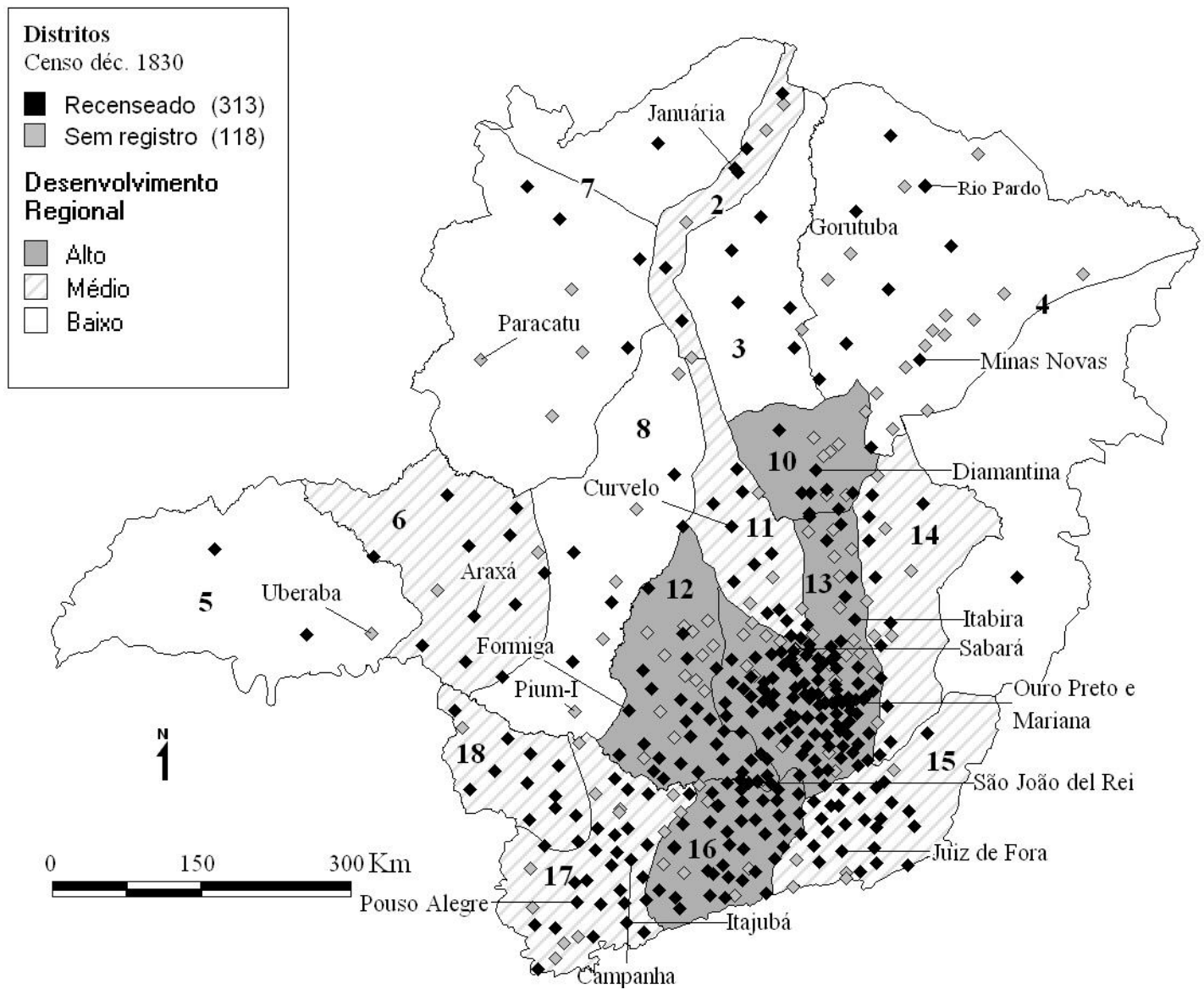

Nota: Regiões pela definição de Godoy (1996): 2-Vale do Alto-Médio Rio São Francisco; 3-Sertão; 4Minas Novas e Sertão do Rio Doce (agregadas); 5-Triângulo; 6-Araxá; 7-Paracatu e Extremo Noroeste (agregadas); 8-Sertão Alto Rio São Francisco; 9-; 10-Diamantina; 11-Vale do Médio-Baixo Rio das Velhas; 12-Intermediária de Pitanguí-Tamanduá; 13-Mineradora Central Oeste; 14-Mineradora Central Leste; 15-Mata; 16-Sudeste; 17-Sul Central; 18-Sudoeste. Níveis de desenvolvimento definidos por Paiva (1996).

Fonte dos dados básicos: IBGE. Malha municipal do Brasil, 1997. Diretoria de Geociências. Departamento de Cartografia.

Importante ressaltar que a unidade de informação das estatísticas vitais é a paróquia, que pode incluir vários distritos de paz. Identificar dentro de cada paróquia os distritos que a compõem não é uma tarefa simples. Até o momento o único documento que nos apontou essa correspondência foi o trabalho de Feu de Carvalho, que traz a listagem dos distritos que compunham as freguesias em 1830. Com base na listagem de Feu de Carvalho (1922) sobre 1830, relacionamos 16 municípios, 99 paróquias e 293 distritos (média de 2,95 distritos por paróquia). As listas nominativas, que abrangem o 
período de 1831/32, apresentam 16 municípios e 431 distritos, mas para essa listagem não temos a indicação de paróquias. A essas duas fontes acrescentamos uma terceira, a obra de Barbosa (1995), que descreve a história das cidades mineiras, onde foi possível reconstruir parte desse passado, e além dessas foi realizado estudo em que verificamos as alterações administrativas através das leis da época. Unindo todas essas fontes, estima-se que os 431 distritos de 1831/32 eram atendidos por 130 paróquias $(3,31$ distritos por paróquia). Com as alterações legislativas, esse número passou no período de 1836 até 1839 para 133 paróquias (3,2 distritos por paróquia) e na década de 1840 o número de paróquias se elevou para 160 (2,69 distritos por paróquia). Esse foi um período de destaque em que diversos curatos foram elevados a freguesia por lei. Abaixo segue o georreferenciamento das paróquias no período do tempo que inclui $1838^{14}$.

A distribuição espacial das paróquias mostra que elas estão representadas em todas as regiões, o que contribui para verificarmos o grau de cobertura dos dados dos mapas de nascimentos, casamentos e óbitos. Há áreas de certa concentração demográfica, como Mineradora Central Oeste, Intermediária de Pitangui e Sudoeste, essas são regiões que se beneficiaram do fluxo de indivíduos, e por isso foram as regiões que aumentaram o número de paróquias.

O banco de dados apresentado neste artigo refere-se ao ano de 1838, por ser o ano com maior número de mapas coletados. No Erro! Fonte de referência não encontrada. foram georreferenciadas as 133 paróquias que existiam no período de 1836 a 1839. Contudo, nosso banco de dados inclui apenas 65 paróquias deste total de 133 , correspondendo a $49 \%$.

\footnotetext{
${ }^{14}$ De acordo com o georreferenciamento e legislação vigente, o número de paróquias varia ao longo do tempo sendo 130 em 1831-1835 e 160 em 1840.
} 
Mapa 2: Sedes das paróquias de 1838, por região e níveis de desenvolvimento regionais - Minas Gerais - Década de 1830

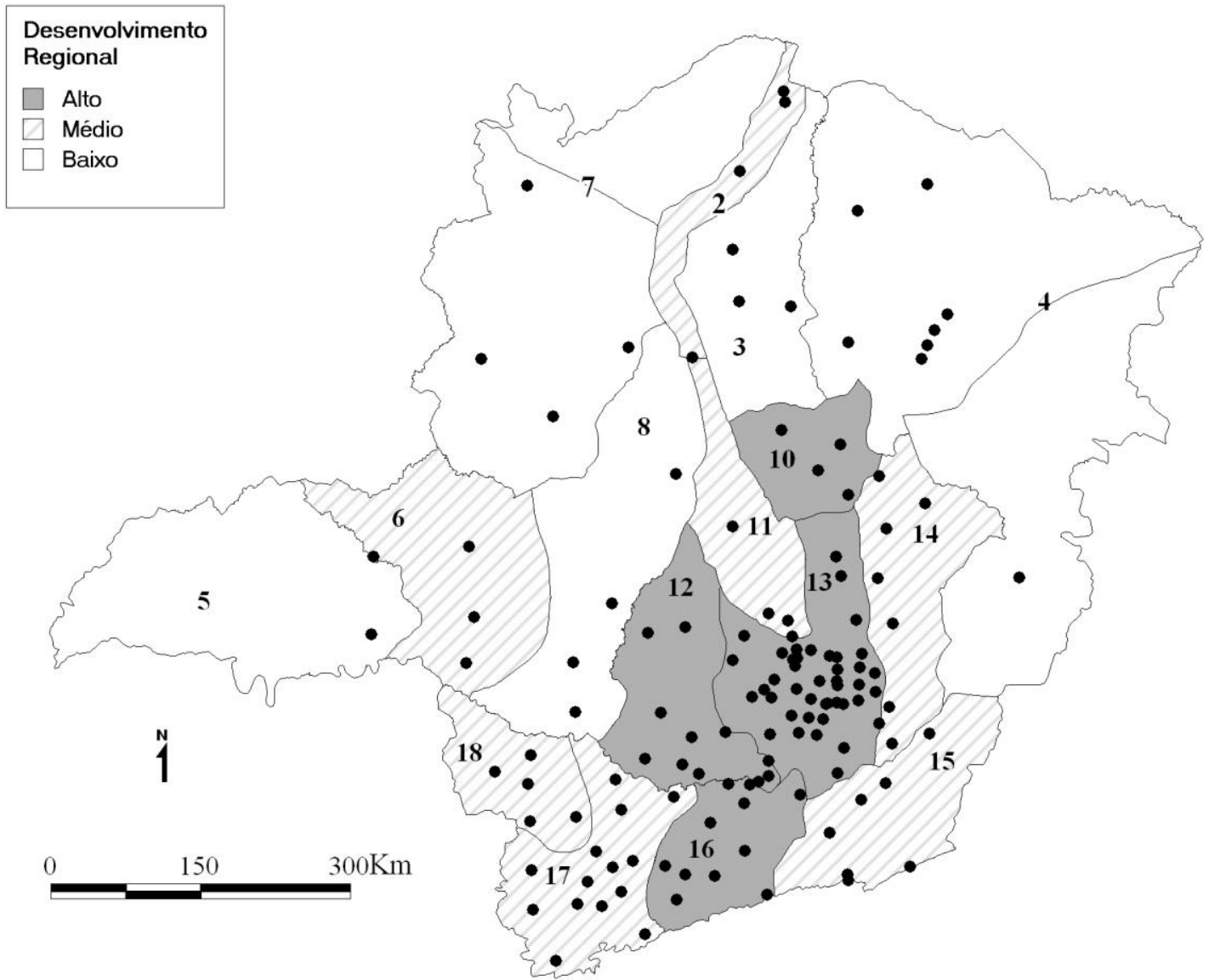

Nota: Regiões pela definição de Godoy (1996): 2-Vale do Alto-Médio Rio São Francisco; 3-Sertão; 4-Minas Novas e Sertão do Rio Doce (agregadas); 5-Triângulo; 6-Araxá; 7-Paracatu e Extremo Noroeste (agregadas); 8-Sertão Alto Rio São Francisco; 9-; 10-Diamantina; 11-Vale do Médio-Baixo Rio das Velhas; 12-Intermediária de PitanguíTamanduá; 13-Mineradora Central Oeste; 14-Mineradora Central Leste; 15-Mata; 16-Sudeste; 17-Sul Central; 18Sudoeste. Níveis de desenvolvimento definidos por Paiva (1996).

Fonte dos dados básicos: IBGE. Malha municipal do Brasil, 1997. Diretoria de Geociências. Departamento de Cartografia. Paróquias: levantamento a partir de Carvalho (1922) e Barbosa (1995).

As 65 paróquias com dados para o ano de 1838 estão espalhadas pela Província, com certa concentração nas regiões mineradoras, o que era esperado, dada a importância econômica da região (Erro! Fonte de referência não encontrada.). Exceto na região do Extremo Noroeste, que é apontada como uma região pouco habitada por Godoy (1996), temos, pelo menos, uma paróquia representando cada uma das regiões, o que confere um caráter de abrangência espacial interessante e sinaliza que esse ano tem uma boa cobertura espacial da Província. Essas 65 paróquias atendiam 203 distritos de Minas Gerais, representando $47 \%$ dos distritos arrolados nas listas nominativas da década de 
1830. A seguir foram apresentados os bancos de dados de nascimentos, casamentos e óbitos.

\section{Mapa 3: Paróquias com dados de nascimentos, casamentos e óbitos de 1838, por região e níveis de desenvolvimento regionais - Minas Gerais - Década de 1830}

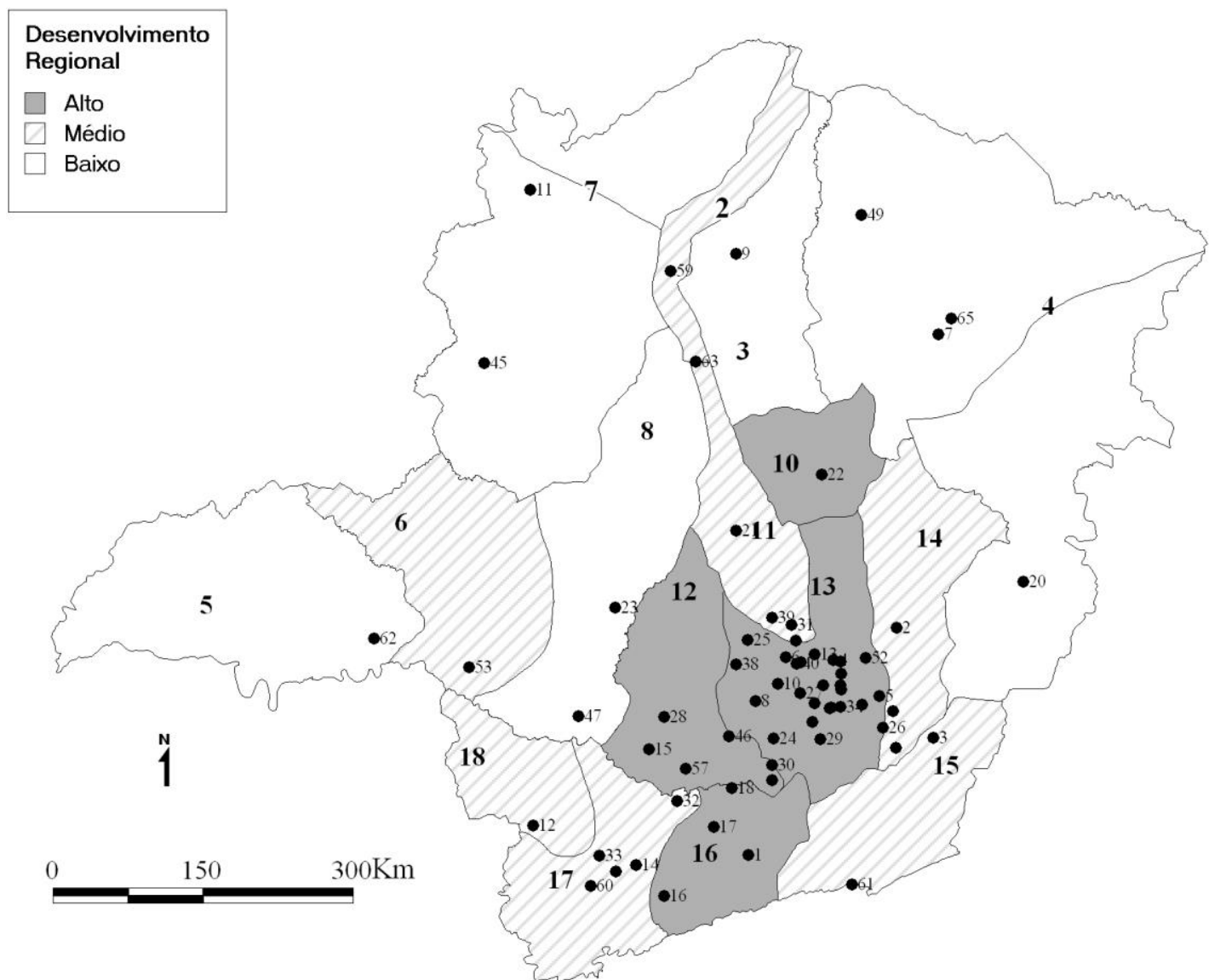

Nota: Regiões pela definição de Godoy (1996): 2-Vale do Alto-Médio Rio São Francisco; 3-Sertão; 4-Minas Novas e Sertão do Rio Doce (agregadas); 5-Triângulo; 6-Araxá; 7-Paracatu e Extremo Noroeste (agregadas); 8-Sertão Alto Rio São Francisco; 9-; 10-Diamantina; 11-Vale do Médio-Baixo Rio das Velhas; 12-Intermediária de PitanguíTamanduá; 13-Mineradora Central Oeste; 14-Mineradora Central Leste; 15-Mata; 16-Sudeste; 17-Sul Central; 18Sudoeste. Níveis de desenvolvimento definidos por Paiva (1996); Paróquias: 1- N. Sra. Da Conceição do Porto Turvo; 2- N. Sra. De Nazaré de Antônio Dias Abaixo; 3- S. Miguel de Arrepiados; 4- S. João Batista do Morro Grande; 5- S. José da Barra Longa; 6- N. Sra. da Boa Viagem do Curral D'el Rei; 7- N. Sra. da Conceição da Agua Suja; 8- Senhor do Bonfim; 9- Santanna de Contendas; 10- N. Sra. da Piedade do Paraopeba; 11- Buritis; 12- N. Sra. da Assunção do Cabo Verde; 13- N. Sra. Do Bom Sucesso de Caethé; 14- Campanha do Rio Verde; 15- Formigas; 16Carmo do Pouso Alto; 17- N. Sra. da Conceição de Carrancas; 18-Conceição da Barra; 19- N. Sra. da Conceição das Catas Altas; 20- N. Sra. da Conceição do Cuieté; 21- Sto. Ant. do Curvelo; 22- S. Ant. do Tejuco; 23- N. Sra. das Dores do Indaiá; 24- Brumado; 25- Sta. Quitéria; 26- Santanna da Barra do Bacalhau; 27- N. Sra. da Boa Viagem da Itabira do Campo; 28- S. Bento do Tamanduá; 29- S. Ant. de Itaverava; 30- S. Ant. da Lagoa Dourada; 31 - N. Sra. da Saúde da Lagoa Santa; 32- Santanna de Lavras do Funil; 33- S. João do Douradinho; 34- Mariana; 35- Senhor Bom Jesus do Forquim; 36- Inficionado; 37- Camargos; 38- Sto. Ant. do Morro de Mateus Leme; 39- Senhor do Mattozinhos; 40- Congonhas, N. Sra. do Pilar; 41- S. Ant. de Ouro Branco; 42- Ouro Preto; 43- N. Sra. De Nazaré de Cachoeira do Campo; 44- N. Sra. da Conceição de Antônio Dias; 45- S. Ant. da Manga do Paracatu; 46- N. Sra. da Glória do Passatempo; 47- N. Sra do Livramento de Piumhy; 48- Ponte Nova; 49- S. José do Gorutuba; 50- N. Sra. da Conceição de Prados; 51- N. Sra. Da Conceição dos Raposos; 52- S. Miguel; 53- N. Sra. do Desterro; 54- Sto. Ant. do Ribeirão de Sta. Bárbara; 55- S. Bartolomeu; 56- Sta. Luzia; 57- Sto. Ant. do Amparo; 58- S. Gonçalo; 59- Santo Antônio do Manga de São Romão; 60- Santana do Sapucaí; 61- Rio Preto do Prezidio; 62- Sto. Ant. da Uberaba; 63N. Sra. Do Bom Sucesso da Barra do Rio das Velhas; 64- Santa Rita do Turvo; 65- S. Domingos

Fonte dos dados básicos: IBGE. Malha municipal do Brasil, 1997. Diretoria de Geociências. Departamento de Cartografia. 
Fonte: Elaboração própria, a partir dos mapas de nascimentos, casamentos e óbitos datados no ano de 1838.

\section{B. Banco de dados: Mapas de nascimentos}

As 65 paróquias em análise somaram um total de 13.254 nascimentos, apresentando a seguinte distribuição.

Tabela 2 - Distribuição de nascimentos - Minas Gerais, 1838 - 65 de 133 paróquias

\begin{tabular}{|c|c|c|c|c|c|c|c|c|c|c|c|}
\hline \multirow{3}{*}{ Batismo } & \multicolumn{4}{|c|}{ Escravo } & \multicolumn{6}{|c|}{ Livre } & \multirow{3}{*}{ Total Geral } \\
\hline & \multicolumn{2}{|c|}{ Pardo } & \multicolumn{2}{|c|}{ Preto } & \multicolumn{2}{|c|}{ Branco } & \multicolumn{2}{|c|}{ Pardo } & \multicolumn{2}{|c|}{ Preto } & \\
\hline & $\mathbf{H}$ & $\mathbf{M}$ & $\mathbf{H}$ & $\mathbf{M}$ & $\mathbf{H}$ & $\mathbf{M}$ & $\mathbf{H}$ & $\mathbf{M}$ & $\mathbf{H}$ & $\mathbf{M}$ & \\
\hline \multicolumn{12}{|c|}{ Batizados } \\
\hline Expostos & - & - & - & 3 & 54 & 71 & 42 & 29 & - & 6 & 206 \\
\hline Ilegítimos & 194 & 231 & 845 & 883 & 165 & 225 & 655 & 704 & 222 & 209 & 4.333 \\
\hline Legítimos & 112 & 130 & 700 & 765 & 1.358 & 1.290 & 1.820 & 1.680 & 351 & 265 & 8.469 \\
\hline Batizados Total & 305 & 361 & 1.545 & 1.651 & 1.577 & 1.586 & 2.517 & 2.413 & 573 & 479 & 13.007 \\
\hline \multicolumn{12}{|c|}{ Por batizar } \\
\hline Expostos & - & - & - & 3 & - & - & - & 3 & - & - & 6 \\
\hline Ilegítimos & 9 & 3 & 24 & 20 & 50 & 17 & 44 & 50 & 32 & 20 & 268 \\
\hline Legítimos & 3 & 6 & 15 & 12 & 50 & 50 & 47 & 32 & 20 & 9 & 243 \\
\hline Por batizar Total & 12 & 9 & 39 & 35 & 100 & 67 & 91 & 85 & 51 & 29 & 517 \\
\hline Total Geral & 317 & 370 & 1.584 & 1.686 & 1.677 & 1.652 & 2.608 & 2.497 & 624 & 508 & 13.524 \\
\hline
\end{tabular}

Fonte: Elaboração própria, a partir dos mapas de nascimentos de 1838 provenientes da Lei $n^{0} 46^{15}$

No mapa de nascimentos há informações daqueles nascimentos que foram batizados e os que ainda seriam. Acresce a isso, a presença de informações acerca da legitimidade dos nascimentos. A estrutura dos mapas e os dados coletados são uma evidência de como os párocos estavam seguindo as instruções da Lei n. 46.

\footnotetext{
${ }^{15}$ A referida lei encontra-se na disponível em: http://memoria.bn.br/DocReader/docreader.aspx?bib=253634\&PagFis=208. O banco de dados é proveniente da coleta do NPHED da pesquisa Antigos Regimes demográficos e os regimes paroquiais, primeira metade do século XIX.
} 


\section{Gráfico 1- Distribuição de nascimentos por legitimidade - Minas Gerais, 1838 - 65 de 133 paróquias}

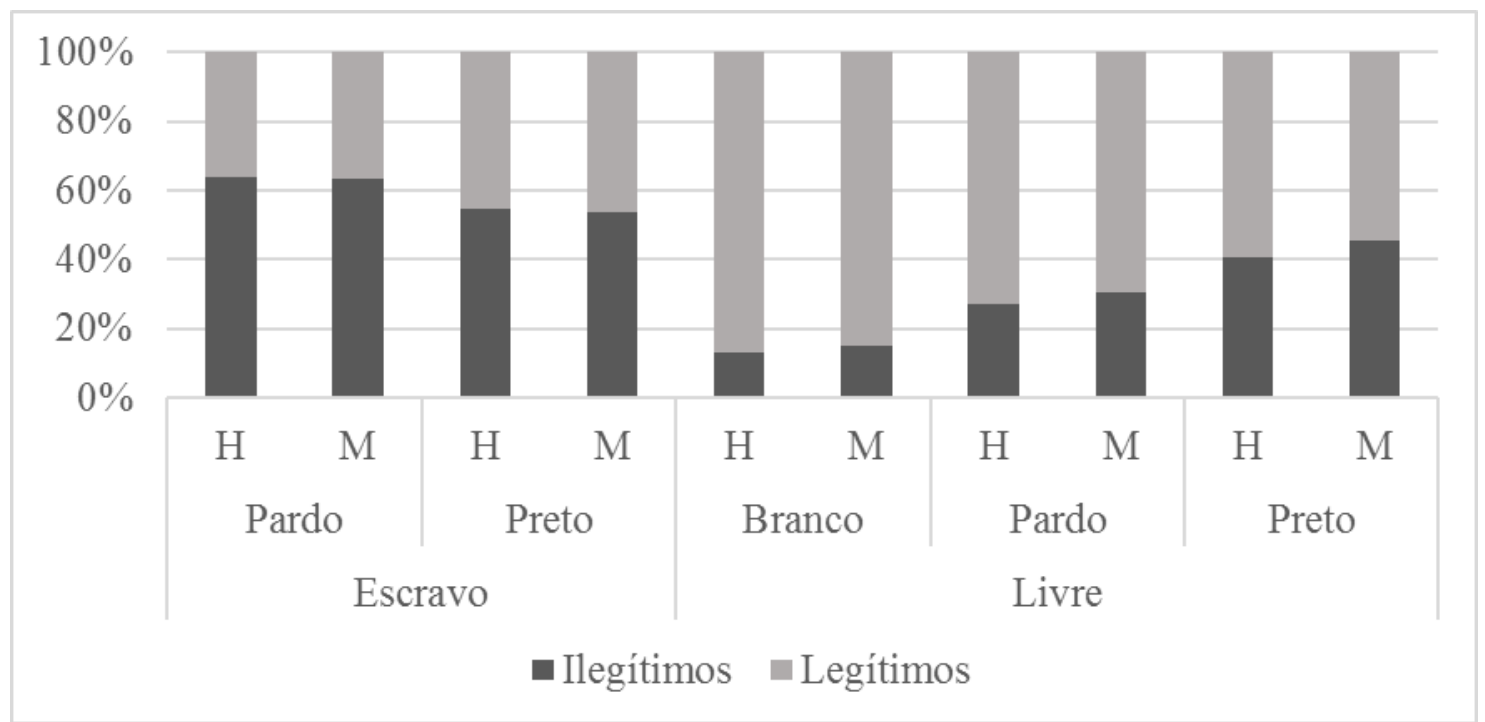

Fonte: Elaboração própria

A ilegitimidade é mais alta na população escrava ena população não branca livre. Esses resultados não são estritamente demográficos, e refletem a mentalidade e sociedade da época.

Outra medida que os mapas de nascimentos permitem é o calculo da Taxa Bruta de Natalidade (TBN) que é a relação entre o número de nascidos vivos e os habitantes. É uma medida que possui suas limitações, porém diante dos dados disponíveis, pode ser aplicada de maneira direta com os dados obtidos. Para a população dos 203 distritos atendidos pelas 65 paróquias em 1838, a TBN desta população é de 30 nascimentos por mil habitantes, sendo da população livre 30,61 nascimentos por mil e da população escrava 27,89 nascimentos por mil. Como comparativo, Teixeira (2005) traz um estudo focado na região de Campinas e na população livre, e os resultados encontrados para o ano de 1794 foram uma natalidade de 53 por mil atingindo 70 por mil em 1814. Já Henry (1977) encontra para população do Paraná em 1822 uma TBN de 48 nascimentos por mil habitantes. Os dados de Teixeira (2005) e Henry (1977) são ilustrativos, pois cada localidade possui suas particularidades, mas de certa forma é um balizador de quão crível são essas estimativas diretas geradas. 


\section{Banco de dados: Casamentos}

As 65 paróquias em análise somaram um total de 5.471 casamentos, apresentando a seguinte distribuição.

Tabela 3- Distribuição de casamentos - Minas Gerais, 1838 - 65 de 133 paróquias

\begin{tabular}{|c|c|c|c|c|c|c|c|c|c|c|c|}
\hline \multirow{3}{*}{ Faixa Etária } & \multicolumn{4}{|c|}{ Escravo } & \multicolumn{6}{|c|}{ Livre } & \multirow{3}{*}{ Total } \\
\hline & \multicolumn{2}{|c|}{ Pardo } & \multicolumn{2}{|c|}{ Preto } & \multicolumn{2}{|c|}{ Branco } & \multicolumn{2}{|c|}{ Pardo } & \multicolumn{2}{|c|}{ Preto } & \\
\hline & $\mathbf{H}$ & $\mathbf{M}$ & $\mathbf{H}$ & $\mathbf{M}$ & $\mathbf{H}$ & $\mathbf{M}$ & $\mathbf{H}$ & $\mathbf{M}$ & $\mathbf{H}$ & $\mathbf{M}$ & \\
\hline Até 14 Anos & 3 & 10 & 7 & 25 & 7 & 63 & 1 & 85 & - & 10 & 209 \\
\hline De 15 a 19 & 19 & 37 & 63 & 146 & 112 & 317 & 165 & 454 & 18 & 89 & 1.420 \\
\hline De 20 a 29 & 53 & 45 & 187 & 164 & 374 & 234 & 570 & 388 & 139 & 112 & 2.267 \\
\hline De 30 a 39 & 37 & 31 & 126 & 71 & 141 & 52 & 269 & 138 & 72 & 51 & 988 \\
\hline De 40 a 49 & 18 & 10 & 46 & 25 & 46 & 27 & 89 & 57 & 53 & 40 & 411 \\
\hline De 50 a 59 & 5 & 1 & 11 & 10 & 12 & 10 & 29 & 7 & 22 & 14 & 120 \\
\hline De 60 a 69 & 4 & 1 & 4 & - & 7 & 1 & 10 & 5 & 8 & 5 & 46 \\
\hline De 70 em diante & - & - & - & - & 4 & - & 3 & - & 1 & - & 8 \\
\hline Total Geral & 139 & 135 & 444 & 440 & 704 & 704 & 1.136 & 1.134 & 314 & 320 & 5.471 \\
\hline
\end{tabular}

Fonte: Elaboração própria, a partir dos mapas de casamentos de 1838 provenientes da Lei $n^{0} 46^{16}$.

Os casamentos concentram-se na população livre, que representam $78 \%$ das uniões registradas pelos párocos, e 67\% das uniões ocorrem na faixa etária de 15 a 29 anos, mostrando o padrão de casamento jovem.

O Gráfico 2 mostra a distribuição dos casamentos por condição, qualidade (cor), sexo e faixa etária. Entre as mulheres, as brancas são as que se casam mais jovens sendo que quase $90 \%$ das uniões de mulheres brancas ocorrem até os 29 anos. Já as mulheres pretas livres são as que se casam mais tardiamente sendo que $90 \%$ ocorrem até aos 39 anos. Os homens em geral casam mais tardiamente, porém os brancos são os que mais antecipam a união.

\footnotetext{
${ }^{16}$ A referida lei encontra-se na disponível em: http://memoria.bn.br/DocReader/docreader.aspx?bib=253634\&PagFis=208. O banco de dados é proveniente da coleta do NPHED da pesquisa Antigos Regimes demográficos e os regimes paroquiais, primeira metade do século XIX.
} 
Gráfico 2 - Distribuição dos casamentos por faixa etária, condição e qualidade Minas Gerais, 1838 - 65 de 133 paróquias

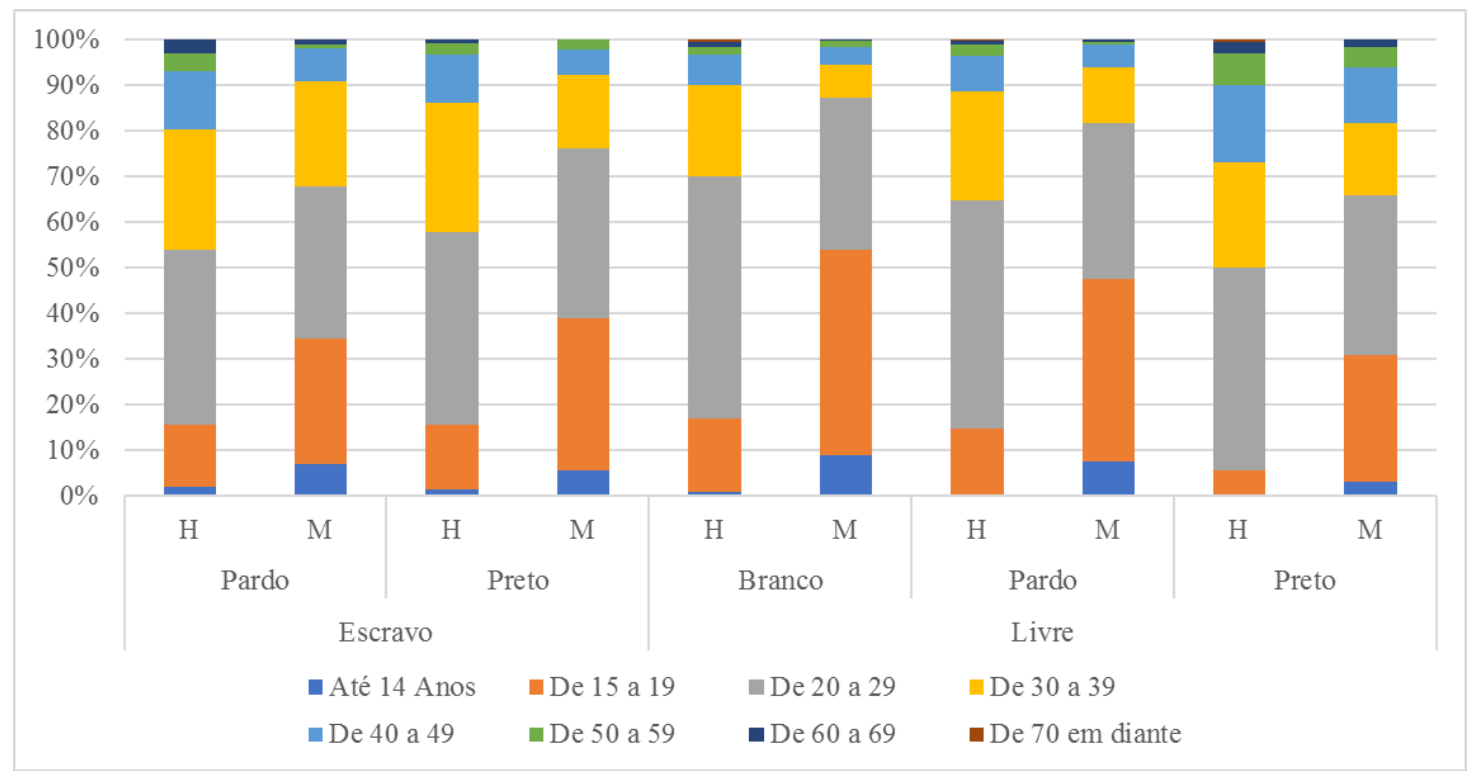

Fonte: Elaboração própria, a partir de Tabela 3. 


\section{Banco de dados: Óbitos}

As 65 paróquias em análise somaram um total de 8.515 óbitos, apresentando a seguinte distribuição.

Tabela 4 - Distribuição de óbitos - Minas Gerais, 1838 - 65 de 133 paróquias

\begin{tabular}{|c|c|c|c|c|c|c|c|c|c|c|c|}
\hline \multirow{3}{*}{$\begin{array}{c}\text { Condição } \\
\text { Qualidade (cor) } \\
\text { Sexo }\end{array}$} & \multicolumn{6}{|c|}{ Livre } & \multicolumn{4}{|c|}{ Escravo } & \multirow{3}{*}{ Total Geral } \\
\hline & \multicolumn{2}{|c|}{ Branco } & \multicolumn{2}{|c|}{ Pardo } & \multicolumn{2}{|c|}{ Preto } & \multicolumn{2}{|c|}{ Pardo } & \multicolumn{2}{|c|}{ Preto } & \\
\hline & $\mathrm{H}$ & $\mathrm{M}$ & $\mathrm{H}$ & $\mathrm{M}$ & $\mathrm{H}$ & $\mathrm{M}$ & $\mathrm{H}$ & $\mathrm{M}$ & $\mathrm{H}$ & $\mathrm{M}$ & \\
\hline Até 9 anos & 440 & 343 & 698 & 528 & 185 & 134 & 89 & 38 & 474 & 327 & 3.256 \\
\hline De 10 a 19 & 49 & 56 & 114 & 104 & 37 & 27 & 32 & 18 & 108 & 75 & 620 \\
\hline De 20 a 29 & 74 & 51 & 131 & 94 & 56 & 59 & 24 & 16 & 145 & 91 & 741 \\
\hline De 30 a 39 & 51 & 64 & 181 & 139 & 45 & 53 & 20 & 26 & 192 & 101 & 872 \\
\hline De 40 a 49 & 88 & 59 & 135 & 121 & 89 & 68 & 31 & 16 & 131 & 100 & 838 \\
\hline De 50 a 59 & 91 & 42 & 138 & 108 & 83 & 64 & 20 & 16 & 106 & 59 & 727 \\
\hline De 60 a 69 & 70 & 64 & 95 & 95 & 67 & 62 & 18 & 8 & 72 & 32 & 583 \\
\hline De 70 a 79 & 63 & 45 & 83 & 45 & 58 & 51 & 15 & 8 & 61 & 26 & 455 \\
\hline De 80 a 89 & 43 & 33 & 36 & 40 & 34 & 32 & 8 & 6 & 31 & 26 & 289 \\
\hline De 90 a 99 & 7 & 17 & 22 & 28 & 12 & 10 & 1 & 0 & 10 & 7 & 114 \\
\hline De 100 em diante & 1 & 6 & 3 & 3 & 1 & 4 & 0 & 0 & 2 & 0 & 20 \\
\hline
\end{tabular}

$\begin{array}{llllllllllll}\text { Total Geral } & 977 & 780 & 1636 & 1305 & 667 & 564 & 258 & 152 & 1332 & 844 & 8.515\end{array}$

Fonte: Elaboração própria, a partir dos mapas de casamentos de 1838 provenientes da Lei $n^{0} 46^{17}$.

${ }^{17}$ A referida lei encontra-se na disponível em http://memoria.bn.br/DocReader/docreader.aspx?bib=253634\&PagFis=208. O banco de dados é proveniente da coleta do NPHED da pesquisa Antigos Regimes demográficos e os regimes paroquiais, primeira metade do século XIX. 


\section{Gráfico 3 - Distribuição do total de mortes por faixa etária decenal - Minas Gerais,} 1838 - 65 de 133 paróquias

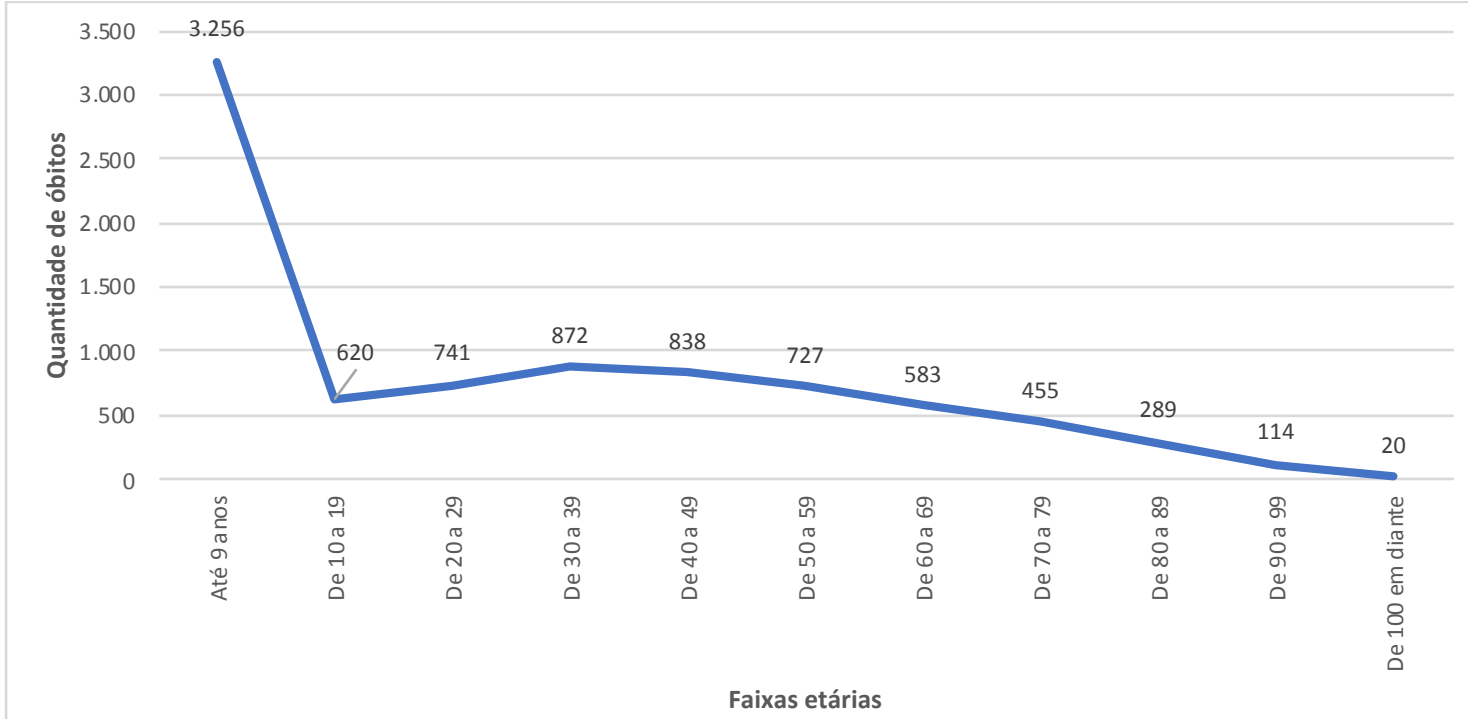

Fonte: Elaboração própria, a partir da Tabela 4.

Há uma concentração de mortes nas faixas etárias mais jovens, o que era esperado, uma vez que o século XIX ainda é um momento pré-transição demográfica no Brasil, logo, as populações são marcadas por regimes de alta fecundidade e mortalidade. Porém é preocupante o número de óbitos de pessoas de 50 anos ou mais sendo registrados, pois esperava-se que não houvesse um expressivo contingente populacional nessas idades, uma vez que Mortara (1941) aponta uma esperança de vida média para a época entre 30 e 35 anos.

O Gráfico 4 representa a mesma idéia que o Gráfico 3, porém separado por sexo. Em números absolutos, os homens morrem mais em todas as faixas etárias até os 89 anos, já as mulheres tem um aumento das mortes dos 20 aos 39 anos e depois as mortes voltam a cair. Essa análise, entretando, deve ser feita com cuidado, pois estamos analisando números absolutos (pode haver um efeito composição etária) e não estamos corrigindo o subregistro dos óbitos. 
Gráfico 4 - Distribuição do total de óbitos por sexo e por faixa etária decenal - Minas Gerais, 1838 65 de 133 paróquias

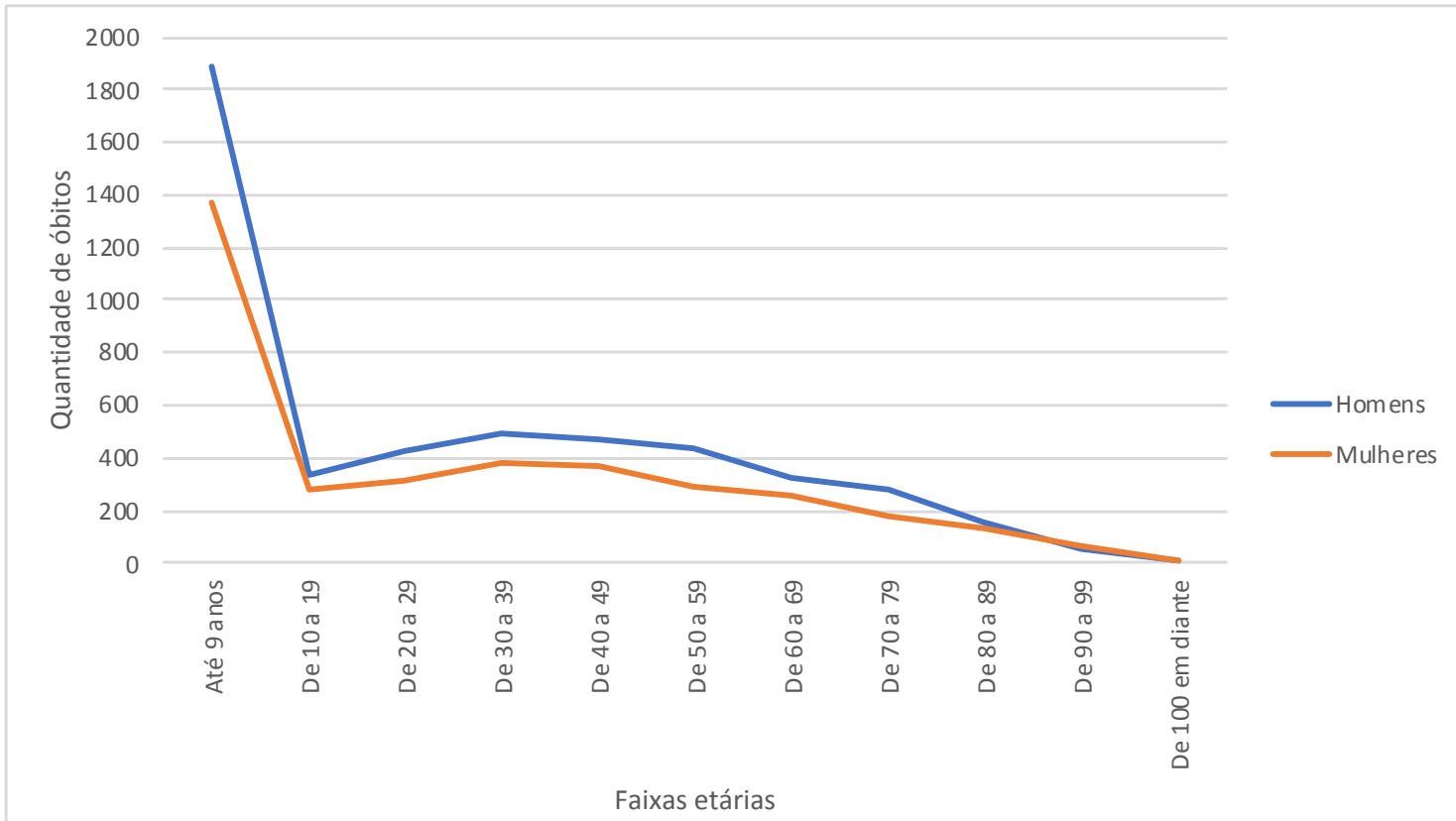

Fonte: Elaboração própria, a partir da Tabela 4.

\section{Considerações finais: avaliação dos mapas de nascimentos, casamentos e óbitos}

É importante salientar que esta é uma experiência pioneira, pois trata-se de uma fonte inédita e única, conforme salientamos ao apresentar a história da elaboração da Lei Provincial n. ${ }^{\circ}$ 46, de 1836. A possibilidade de aplicarmos métodos demográficos para buscar entender questões do passado é a maior conquista deste artigo. Aqui apresentamos uma exploração inicial, pois como todo dado histórico há de se ter o otimismo ao ver o quanto é inovador para a época uma fonte dessa magnitude, mas, ao mesmo tempo, ter a consciência das limitações que a própria fonte possui.

Para isso é preciso aliar a sensibilidade do estudo histórico com a metodologia da análise demográfica e administrar esses dois aspectos a fim de obter estimativas que sejam confiáveis. O exercício inicial proposto aqui é apresentar medidas iniciais que podem ser geradas diretamente e verificar os pontos de maior atenção que necessitam da análise demográfica para sua correção. O que podemos verificar nesta primeira análise é que há informações ricas e que nos mostram resultados surpreendentes mesmo sem tratamento, como os mapas de casamentos, porém, há aqueles que carecem de diversos ajustes, como os mapas de óbitos. 
Aqui não há uma conclusão de todas as medidas que podem ser geradas através das fontes, pois elas são diversas. A disponibilização futura de software online que permita o acesso gratuito para outros pesquisadores da mesma fonte e sem a necessidade de deslocamento tornará o debate e o diálogo ainda mais profícuo em torno dessa importante fonte, contribuindo assim para o que se espera do trabalho acadêmico, um constante processo de aprimoramento e transformação.

\section{Referências}

BACELLAR, Carlos de A. P. Arrolando os habitantes no passado: as listas nominativas sob um olhar crítico. Locus: Revista de História, v. 14, p. 113-132, 2008.

BARBOSA, W. de A. Dicionário Histórico-Geográfico de Minas Gerais. Belo Horizonte: Itatiaia Limitada, 1995.

BOTELHO, Tarcísio R. População e nação no Brasil do século XIX. 1998. 241 f. Tese (Doutorado em História) - Departamento de Ciências Sociais da Faculdade de Filosofia, Letras e Ciências Humanas, Universidade de São Paulo, São Paulo, 1998.

BOXER, Charles R. O Império Colonial Português. São Paulo: Edições 70, 1969. v. 1 .

CARVALHO, Theophilo Feu de. Comarcas e termos: creações, suppreções, restaurações, encorporações e desmenbramentos de comarcas e termos, em Minas Gerais (1709-1915). Belo Horizonte: Imprensa Official, 1922.

DIAS, Maria O. A interiorização da metrópole. In: MOTA, Carlos Guilherme. 1822: dimensões. São Paulo: Perspectiva, 1972. 487p.

DINIZ, Sarah G.; RODARTE, Mario M. S. Estatística Populacional nas Minas Oitocentista - Estudo de Caso: 1845. XIX Encontro Nacional de Estudos Populacionais. Anais...São Pedro: 2014

FONSECA, Claudia D. Arraiais e vilas d'El Rei. Espaço e poder nas Minas setecentistas. (2011).

FURTADO, Celso. O longo amanhecer: reflexões sobre a formação do Brasil. [2. ed.]. Rio de Janeiro: Paz e Terra, 1999. 116 p.

GODOY, Marcelo M. Intrépidos viajantes e a construção do espaço: uma proposta de regionalização para as Minas Gerais do século XIX. Belo Horizonte: Cedeplar/UFMG, 1996. 112 p. (Texto para discussão, 109).

<http://www.cedeplar.ufmg.br/pesquisas/td/TD\%20109.pdf> Acesso em 2 jul 2019.

HENRY, Louis. Técnicas de análise em demografia histórica. Curitiba: Univ. Federal do Parana, 1977. 165p.

PAIVA, Clotilde A. População e economia nas Minas Gerais do século XIX. 1996. 229 f. Tese (Doutorado de História) - Departamento de Ciências Sociais da Faculdade de Filosofia, Letras e Ciências Humanas, Universidade de São Paulo, São Paulo, 1996. Disponível 
http://www.nphed.cedeplar.ufmg.br/wpcontent/uploads/2017/05/Tese_Clotilde_PAIVA _v1996.pdf. Acesso em: 2 jul. 2019.

PAIVA, E. F; FERNANDEZ CHAVES, M. F. (Org.) ; PEREZ GARCIA, R. M. (Org.) . De que estamos falando? Antigos conceitos e modernos anacronismos: escravidão e mestiçagens.. 1. ed. Rio de Janeiro: Garamond, 2016. v. 1. 226p .

PAIVA, E. F. Dar nome ao novo: uma história lexical da Ibero-América, entre os séculos XVI e XVIII (as dinâmicas de mestiçagens e o mundo do trabalho).. 1. ed. Belo Horizonte: Autêntica, 2015. v. 1. 304p .

RODARTE, Mario M. S. O trabalho do fogo: Perfis de domicílios enquanto unidades de produção e reprodução na Minas Gerais Oitocentista. 2008, 365 f. Tese (Doutorado em Demografia) - Centro de Desenvolvimento e Planejamento Regional, Universidade Federal de Minas Gerais, Belo Horizonte, 2008.

SENRA, Nelson. História das estatísticas Brasileiras: Estatísticas desejadas (1822-c. 1889). 1. ed. Rio de Janeiro: IBGE, 2006. v. 1. $611 \mathrm{p}$.

SILVA, J. N. S. Investigações sobre os Recenseamentos da População Geral do Império e de cada Província per si tentados desde os tempos coloniais até hoje. Rio de Janeiro, 1870.

TEIXEIRA, H. M. A labuta sem ciranda: crianças pobres e trabalho em Mariana. História. Questões e Debates, v. 24, 2006. Disponível em: http://www.cedeplar.ufmg.br/seminarios/seminario_diamantina/2006/D06A051.pdf

Acesso em: 9 jul. 2019

\section{LEGISLAÇÃO E RELATÓRIOS DA ÉPOCA}

Lei Mineira n. ${ }^{\circ} 46$ de 1836, disponível em: http://memoria.bn.br/DocReader/docreader.aspx ?bib=253634\&PagFis=208. Acesso em 13 out. 2013.

Regimento $\quad$. $^{\circ} \quad 8$ de $1836, \quad$ disponível em: http://memoria.bn.br/DocReader/docreader.aspx $? \mathrm{bib}=253634 \&$ PagFis=298. Acesso em 13 out. 2013.

Relatórios de Presidente de Província, 1837 a 1862. Disponíveis em:

http://ddsnext.crl.edu/titles/171\#?c=4\&m=0\&s=0\&cv=0\&r=0\&xywh=673\%2C762\%2C2459\%2C1734. Acesso em: 15 out de 2013.

Legislação vigente de 1836 a 1850. Cartas de Lei que tratam da criação e limites de diversas freguesias. 